\title{
Clinical impact of duodenal pancreatic heterotopia - Is there a need for surgical treatment?
}

\author{
Alexander Betzler ${ }^{1}$, Soeren T. Mees ${ }^{1}$, Josefine Pump ${ }^{1}$, Sebastian Schölch', Carolin Zimmermann ${ }^{1}$, Daniela E. Aust ${ }^{2}$,
} Jürgen Weitz ${ }^{1}$, Thilo Welsch ${ }^{1}$ and Marius Distler ${ }^{1 *}$ (D)

\begin{abstract}
Background: Pancreatic heterotopia (PH) is defined as ectopic pancreatic tissue outside the normal pancreas and its vasculature and duct system. Most frequently, PH is detected incidentally by histopathological examination. The aim of the present study was to analyze a large single-center series of duodenal PH with respect to the clinical presentation.

Methods: A prospective pancreatic database was retrospectively analyzed for cases of $\mathrm{PH}$ of the duodenum. All pancreatic and duodenal resections performed between January 2000 and October 2015 were included and screened for histopathologically proven duodenal PH. PH was classified according to Heinrich's classification (Type I acini, ducts, and islet cells; Type II acini and ducts; Type III only ducts).

Results: A total of 1274 pancreatic and duodenal resections were performed within the study period, and 67 cases of $\mathrm{PH}$ (5.3\%) were identified. The respective patients were predominantly male (72\%) and either underwent pancreatoduodenectomy $(n=60)$; a limited pancreas resection with partial duodenal resection $(n=4)$; distal pancreatectomy with partial duodenal resection $(n=1)$; total pancreatectomy $(n=1)$; or enucleation $(n=1)$. Whereas 65 patients (83.5\%) were asymptomatic, 11 patients (18.4\%) presented with symptoms related to $\mathrm{PH}$ (most frequently with abdominal pain [72\%] and duodenal obstruction [55\%]). Of those, seven patients (63.6\%) had chronic pancreatitis in the heterotopic pancreas. The risk of malignant transformation into adenocarcinoma was $2.9 \%$.

Conclusions: $\mathrm{PH}$ is found in approximately $5 \%$ of pancreatic or duodenal resections and is generally asymptomatic. Chronic pancreatitis is not uncommon in heterotopic pancreatic tissue, and even there is a risk of malignant transformation. PH should be considered for the differential diagnosis of duodenal lesions and surgery should be considered, especially in symptomatic cases.
\end{abstract}

Keywords: Pancreatic heterotopia, Pancreatic resection, Heinrich's classification, Pancreatic cancer, Chronic pancreatitis

\section{Background}

Pancreatic heterotopia (PH) was first reported by Jean-Schultz in 1729 and is defined as pancreatic tissue without anatomical or vascular connection to the pancreas [1, 2].

The ectopic pancreatic tissue possesses its own duct system and vascular supply [3,4]. It is mostly found in

\footnotetext{
* Correspondence: Marius.Distler@uniklinikum-dresden.de

1 Department of General, Thoracic and Vascular Surgery, University Hospital Carl Gustav Carus, TU Dresden, Fetscher Str. 74, 01037 Dresden, Germany

Full list of author information is available at the end of the article
}

the upper gastrointestinal tract (GIT), but may occur anywhere in the GIT $[5,6]$. Frequent locations are the duodenum (93.6\%), stomach (24-38\%), jejunum (0.5-27\%), and Meckel's diverticulum (2-6.5\%) [7]. The most widespread explanation of the origin of $\mathrm{PH}$ is that the ectopic tissue separates itself from the pancreas during embryonic rotation and fusion of the dorsal and ventral pancreatic buds (misplacement theory) [3, 8]. For a clinical understanding of $\mathrm{PH}$ it is important to know that all diseases arising in the genuine pancreas can also develop in heterotopic tissue $[3,6,9,10]$.

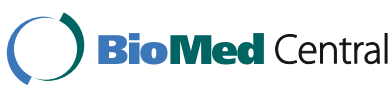

(c) The Author(s). 2017 Open Access This article is distributed under the terms of the Creative Commons Attribution 4.0 International License (http://creativecommons.org/licenses/by/4.0/), which permits unrestricted use, distribution, and reproduction in any medium, provided you give appropriate credit to the original author(s) and the source, provide a link to the Creative Commons license, and indicate if changes were made. The Creative Commons Public Domain Dedication waiver (http://creativecommons.org/publicdomain/zero/1.0/) applies to the data made available in this article, unless otherwise stated. 
Among all abdominal surgeries the incidence of $\mathrm{PH}$ ranges from $0.25-1.2 \%$, and specific symptoms have not been described until now [11]. Most patients with $\mathrm{PH}$ are asymptomatic, and $\mathrm{PH}$ is detected incidentally by histological examination of the specimen. Although malignant transformation originating from $\mathrm{PH}$ is extremely rare, it has been reported in several cases in the literature $[12,13]$. Because of the scarcity of symptomatic $\mathrm{PH}$ cases in the literature $[6,14-16]$, we investigated our series of duodenal $\mathrm{PH}$ with a special focus on its clinical relevance and impact.

\section{Methods}

We retrospectively analyzed our prospective pancreatic database for cases with $\mathrm{PH}$ of the duodenum. All pancreatic and duodenal resections performed at the Department of Visceral, Thoracic and Vascular Surgery, University Hospital, TU Dresden between January 2000 and October 2015 were included. Partial results have been published elsewhere [17]. Clinical symptoms, surgical procedures and pathological findings were documented for each case. At histological examination, the specimens were stained with hematoxylin and eosin, and a senior GI pathologist (DEA) reviewed each sample regarding the components of pancreatic tissue (including acini, ducts, and islets of Langerhans). $\mathrm{PH}$ was classified according to Heinrich's classification (Fig. 1) [18]. Briefly,
PH Type I includes acini, ducts and endocrine islet cells, Type II contains acini and ducts, but no islet cells, and Type III contains only pancreatic ducts.

$\mathrm{PH}$ was classified as "symptomatic" if the surgery was directly indicated for $\mathrm{PH}$-associated pathologies, whereas incidental $\mathrm{PH}$ diagnosed on postoperative histopathological examination was classified as "asymptomatic". We compared these two groups regarding type of $\mathrm{PH}$, associated disease and treatment.

In accordance with the guidelines for human subject research, approval was obtained from the ethics committee at the Carl Gustav Carus University Hospital (decision number EK 435102015).

\section{Results}

\section{Patient cohort}

In total, 1274 pancreatic and duodenal resections were performed in our department during the study period. Some 67 cases $(5.3 \%)$ with histologically proven duodenal $\mathrm{PH}$ were identified (19 women and 49 men). The mean age of the whole cohort was 54 years (range 2476 years). The postoperative histology showed chronic pancreatitis $(\mathrm{CP})(n=25 ; 37.3 \%)$, pancreatic ductal adenocarcinomas (PDAC) $(n=11 ; 16.4 \%)$, and cystic neoplasms $(n=11 ; 16.4 \%)$. Nine operated patients (13.4\%) had papillary carcinomas (AP) and six (9\%) presented with neuroendocrine tumors (NET). More rare

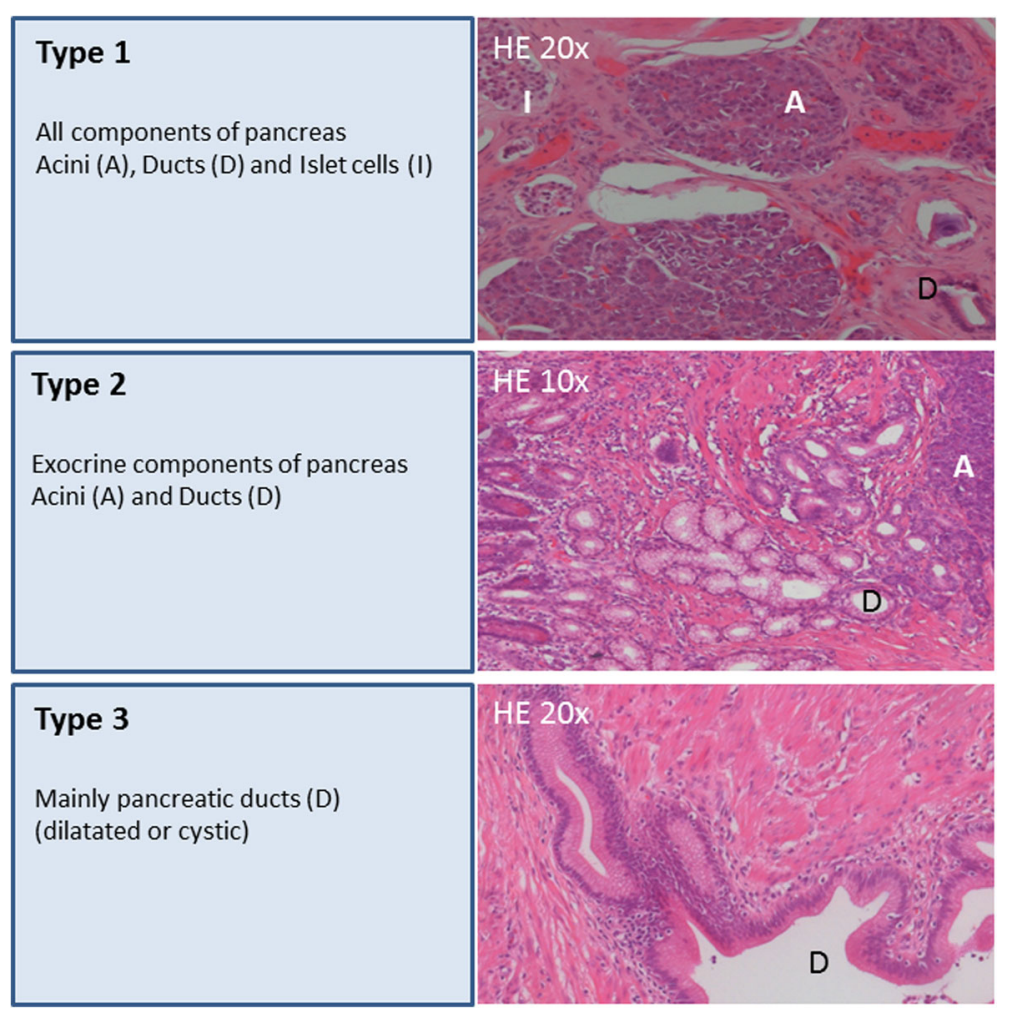

Fig. 1 Heinrich's classification of pancreatic heterotopia 
indications for operation included duodenal polyps (two cases; $2.9 \%$ ), one cholangiocarcinoma, one pancreas divisum, and one duodenal carcinoma (Tables 1 and 2). Pancreatic head resections including pylorus-preserving pancreatoduodenectomies (PPPD) and Whipple procedures represented the vast majority of the operations $(n=60 ; 89.5 \%)$. In four cases $(5.9 \%)$ a segmental pancreatic resection with partial duodenal resection was performed. Furthermore, one patient each underwent a distal pancreatectomy with partial duodenal resection, a total pancreatectomy and an enucleation of the pancreas and the duodenum (1.4\%). According to Heinrich's classification, Type I PH was found in 32 patients $(47.9 \%)$, Type II in 28 patients (41.7\%), and Type III in 7 patients (10.4\%) (Tables 1 and 2).

\section{"Asymptomatic" subgroup}

Fifty-six of the 67 patients (83.5\%) were classified as asymptomatic. Performed operations, and postoperative histology are shown on Table 1. In this subgroup the following types of heterotopia were diagnosed: Type I, $n=26$; Type II, $n=24$; and Type III, $n=6$. The patients in the "asymptomatic" cohort presented with the following complaints of the underlying non$\mathrm{PH}$ associated disease (e.g., pancreatic malignancy or chronic pancreatitis): obstructive jaundice, upper abdominal pain, vomiting/nausea, weight loss or duodenal obstruction (Table 1).

\section{"Symptomatic" subgroup}

In 11 cases $(16.4 \%)$ duodenal $\mathrm{PH}$ was responsible for the clinical symptoms (symptomatic subgroup) (Table 2). In this subgroup Heinrich's Type I and II were predominantly found (Type I $n=6$; Type II $n=4$ and Type III $n=1)$. Interestingly, the most frequent $\mathrm{PH}$-related symptom was upper abdominal pain $(n=8,72 \%)$, and duodenal obstruction $(n=6,55 \%)$. The postoperative histological examination of the symptomatic patients revealed chronic pancreatitis in 7 patients (64\%), PDAC in two patients $(18 \%)$, and duodenal tumors in two cases (18\%) originating from the existing duodenal $\mathrm{PH}$. There was no difference in age, sex and type of surgery between the two groups, and there was no significant difference regarding related disease or Heinrich type $(p>0.05)$ between the symptomatic and asymptomatic cases (Table 3).

\section{Discussion}

$\mathrm{PH}$ is described as a rare pathological entity, and a preoperative clinical diagnosis is difficult because characteristic clinical symptoms are frequently camouflaged by the multitude of underlying diseases [3, 6, 19]. Clinical series are rare and most data in the literature stem from case reports.

The present study focused on duodenal PH. Approximately $5 \%$ of the patients undergoing pancreatic and/or duodenal resections in our cohort were diagnosed with $\mathrm{PH}$, and thus $\mathrm{PH}$ was not a particularly

Table 1 Characteristics of "asymptomatic patients" with duodenal PH $(n=56)$ (Indication for operation due to clinical presentation and symptoms)

\begin{tabular}{|c|c|c|c|c|}
\hline $\begin{array}{l}\text { Type of duodenal PH } \\
\text { (according to Heinrich) }\end{array}$ & $\begin{array}{l}\text { Age (mean) } \\
\text { Sex }(m / f)\end{array}$ & Operation & Clinical presentation and symptoms ${ }^{a}$ & Histology \\
\hline Type $1 n=26$ & $\begin{array}{l}57.4 \text { years } \\
(16 / 10)\end{array}$ & $\begin{array}{l}\text { 1xpancreatectomie; } \\
\text { 3xWhipple; } \\
\text { 19x PPPD; } \\
\text { 2x partial duodenal resection; } \\
\text { 1x enucleation of the pancreas and the } \\
\text { duodenum }\end{array}$ & $\begin{array}{l}11 \text { xobstructive jaundice } \\
9 x e \text { igastric pain } \\
6 x \text { recurrent pancreatitis } \\
\text { duodenal stenosis } \\
5 x \text { loss of weight } \\
\text { recurrent hypoglycemia } \\
\text { acid reflux }\end{array}$ & $\begin{array}{l}\text { SCN } \\
5 \times P D A C \\
5 \times I P M N \\
6 \times C P \\
5 \times A P \\
4 \times N E T\end{array}$ \\
\hline Type $2 n=24$ & $\begin{array}{l}55.9 \text { years } \\
(18 / 6)\end{array}$ & $\begin{array}{l}\text { 19xPPPD } \\
4 x \text { Whipple } \\
\text { Pancreas left resection }\end{array}$ & $\begin{array}{l}\text { 9xrecurrent pancreatitis } \\
\text { 7xobstructive jaundice } \\
\text { 10xepigastric pain } \\
\text { diarrhoe } \\
\text { 3xdilatation pancreas duct } \\
\text { 2xpseudocyst } \\
\text { 2xduodenal stenosis } \\
\text { 5xweight loss } \\
\text { gastric stenosis } \\
\text { 2xcholestasis }\end{array}$ & $\begin{array}{l}\text { 4xIPMN } \\
\text { Carcinoma of the bile } \\
\text { duct } \\
3 \times A P \\
9 \times C P \\
\text { 2XNET } \\
4 \text { XPDAC } \\
\text { SCN }\end{array}$ \\
\hline Type $3 n=6$ & $\begin{array}{l}57.2 \text { years } \\
(4 / 2)\end{array}$ & $\begin{array}{l}\text { 5xPPPD } \\
\text { 1xWhipple }\end{array}$ & $\begin{array}{l}\text { 2xrecurrent pancreatitis; 3xobstructive } \\
\text { jaundice; 3xepigastric pain; } 1 \text { xpseudocyst; } \\
\text { 1xcystic tumor; 1xampullary tumor; } \\
\text { 1xduodenal stenosis; 1 } 1 \text { dilatation } \\
\text { pancreatic duct }\end{array}$ & $\begin{array}{l}\text { 1xPDAC; } \\
\text { 3xCP; 1xAP; } \\
\text { 1xpancreas divisum }\end{array}$ \\
\hline
\end{tabular}

${ }^{a}$ multiple answers possible;

PDAC pancreatic ductal adenocarcinoma, CPchronic pancreatitis, APampullary carcinoma, SCN serous cystic neoplasia, IPMN intraductal papillary mucinous neoplasia, NET Neuroendocrine tumor 
Table 2 Characteristics of "symptomatic patients" with lesions originating from duodenal PH or symptoms due to duodenal PH $(n=11)$

\begin{tabular}{|c|c|c|c|c|}
\hline $\begin{array}{l}\text { Type of duodenal PH } \\
\text { (according to Heinrich) }\end{array}$ & $\begin{array}{l}\text { Age (mean) } \\
\text { Sex }(m / f)\end{array}$ & Operation & Clinical presentation and symptoms ${ }^{a}$ & Histology \\
\hline Type $1 n=6$ & $\begin{array}{l}58.6 \text { years } \\
(5 / 1)\end{array}$ & 3xWhipple; 3xPPPD & $\begin{array}{l}\text { 3xduodenal stenosis; 4xepigastric pain; } \\
\text { 1xnausea/vomiting; 1xobstructive jaundice; } \\
\text { 1xweigth loss; 1xpseudocysts }\end{array}$ & $\begin{array}{l}3 \times C P \text { in } \mathrm{PH} ; 2 \times P D A C \text { in } \mathrm{PH} \text {; } \\
1 \times \mathrm{PH} \text { in duodenal wall }\end{array}$ \\
\hline Type $2 n=4$ & $\begin{array}{l}47.8 \text { years } \\
(4 / 0)\end{array}$ & $\begin{array}{l}\text { 2xpartial duodenal } \\
\text { resection; } \\
\text { 1xWhipple; 1xPPPD }\end{array}$ & $\begin{array}{l}\text { 3xduodenal stenosis; 3xepigastric pain; } \\
\text { 1xNausea/vomiting; } \\
\text { 1xobstructive jaundice; 1xpseudocysts }\end{array}$ & $\begin{array}{l}1 \times \mathrm{PH} \text { in duodenal wall; } \\
3 \times \mathrm{CP} \text { in } \mathrm{PH}\end{array}$ \\
\hline Type $3 n=1$ & 47.0 years male & PPPD & recurrent epigastric pain & $\mathrm{CP}$ in $\mathrm{PH}$ \\
\hline
\end{tabular}

amultiple answers possible

$P D A C$ pancreatic ductal adenocarcinoma, $C P$ chronic pancreatitis, $P H$ pancreatic heterotopia

rare finding. Our study confirms that most of the patients with $\mathrm{PH}$ were asymptomatic, and therefore $\mathrm{PH}$ was discovered incidentally. However, depending on its location and diameter, heterotopic pancreatic tissue can lead to nonspecific symptoms [20-22]. According to the literature, lesions are more likely to be symptomatic if they are $>2 \mathrm{~cm}$ in diameter [23]. This seems to be especially true for tumors that are located in the duodenum due to the anatomic character of this region of the digestive tract. Nevertheless, due

Table 3 Comparison of the asymptomatic and symptomatic subgroups

\begin{tabular}{|c|c|c|c|}
\hline & $\begin{array}{l}\text { Asymptomatic } \\
\text { Subgroup } n=56\end{array}$ & $\begin{array}{l}\text { Symptomatic } \\
\text { Subgroup } n=11\end{array}$ & $p$-value \\
\hline Mean age y $( \pm S D)$ & $56,7(12.5)$ & $53,6(12.3)$ & $p=0.45$ \\
\hline $\operatorname{Sex}(m / f)$ & $38 / 18$ & $10 / 1$ & $\begin{array}{l}p=0.12 \\
\left(X^{2}=2.405\right)\end{array}$ \\
\hline \multicolumn{4}{|l|}{$\begin{array}{l}\text { Type of surgery } \\
(n=)\end{array}$} \\
\hline PPPD & $n=43$ & $n=5$ & $\begin{array}{l}p=0.10 \\
\left(X^{2}=4.515\right)\end{array}$ \\
\hline Whipple & $n=8$ & $n=4$ & \\
\hline Other & $n=5$ & $n=2$ & \\
\hline \multicolumn{4}{|l|}{$\begin{array}{l}\text { Associated disease } \\
(n=)\end{array}$} \\
\hline PDAC & $n=10$ & $n=2$ & $\begin{array}{l}p=0.05 \\
\left(X^{2}=10.47\right)\end{array}$ \\
\hline $\mathrm{CP}$ & $n=18$ & $n=7$ & \\
\hline Cystic neoplasia & $n=11$ & $n=0$ & \\
\hline NET & $n=6$ & $n=0$ & \\
\hline $\mathrm{AP}$ & $n=9$ & $n=0$ & \\
\hline Other & $n=2$ & $n=2$ & \\
\hline \multicolumn{4}{|l|}{ Heinrich Type } \\
\hline I & 26 & 6 & $\begin{array}{l}p=0.88 \\
\left(X^{2}=0.2428\right)\end{array}$ \\
\hline$\|$ & 24 & 4 & \\
\hline III & 6 & 1 & \\
\hline
\end{tabular}

to a lack of data concerning the diameter of the duodenal PH-lesions we could not make a clear statement to this point. But abdominal pain is the most common -but nonspecific- symptom of pancreatic heterotopia, [4] as found in the present study (73\%). Consequently, the nonspecific set of symptoms makes the clinical diagnosis of $\mathrm{PH}$ challenging; none of the patients in the present analysis was diagnosed with $\mathrm{PH}$ preoperatively.

\section{Differential diagnosis of duodenal heterotopia}

In general, PH lesions in the GIT are detectable by endoscopy. PH often presents as a submucosal swelling covered by normal mucosa and can easily be mistaken as gastrointestinal stroma tumor (GIST) or leiomyoma using endoscopy, ultrasonography or CT scanning [24]. In addition the risk of false negative biopsy results is high because ectopic tissue is most commonly located in the submucosal layer (76\%), and sporadically appears in the muscular layer (15\%), or in the subserosa (9\%) [25]. Therefore, most biopsies are inconclusive, because of inadequate tissue samples [22]. In this context, endoscopic ultrasound-guided fine-needle aspiration (EUS-FNA) has been found to be valuable in the diagnosis of upper GIT lesions [26, 27].

In the present study, endoscopic ultrasound was not one of the standard preoperative investigations but the lesions were differentiated by preoperative CT and/or MRI scans (Fig. 2). If one looks on the presented CT-scan of a duodenal $\mathrm{PH}$, it was especially difficult to distinguish the tumor from the original pancreas because of the close proximity of the two organs (Fig. 2). Based on current data on the value of EUS in the diagnosis of upper GIT lesions, EUS should be performed if a submucosal lesion is suspected. From the clinical point of view it is often impossible to distinguish GIST, lymphomas, peptic ulcer disease, or malignancies from heterotopic pancreatic tissue $[16,20,22]$. To diagnose $\mathrm{PH}$, histopathological examination is therefore essential. 


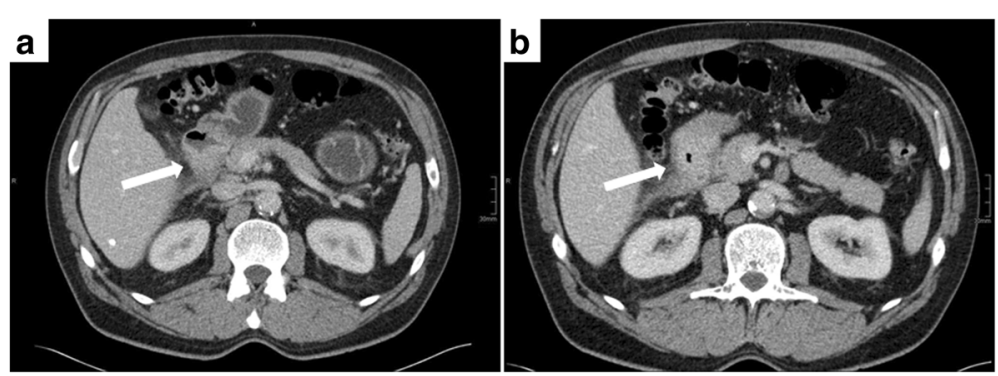

Fig. 2 Computed tomography (CT) scans $(\mathbf{a} / \mathbf{b})$ of a duodenal pancreatic heterotopia (arrows) with a duodenal stenosis

\section{Malignant transformation of pancreatic heterotopia}

Several studies have demonstrated that any disease of the ordinary pancreas can also arise in the heterotopic tissue, such as acute and chronic pancreatitis, the occurrence of pseudocystic changes, or even a malignant transformation to adenocarcinoma or acinar cell carcinoma $[3,6,10,16,28-30]$. The present results are in line with these findings, as two out of 67 patients with $\mathrm{PH}$ developed adenocarcinoma by malignant transformation of the heterotopic pancreatic tissue (2.9\%). Guillou et al. stated that the incidence of malignancy due to heterotopic pancreatic tissue is $0.7 \%$ and therefore is extremely rare [13]. They studied the frequency of malignant transformations among 146 cases of $\mathrm{PH}$ between 1975 and 1991, including surgical and autopsy specimens. In a study by Makhlouf et al. two out of 109 patients (1.8\%) with $\mathrm{PH}$ of the gastrointestinal tract were diagnosed with adenocarcinoma between 1970 and 1997 [12]. Malignancy is therefore a differential diagnosis and should be excluded. Furthermore, histopathological examination of the resected specimen of the 11 symptomatic patients in the present study showed chronic pancreatitis in seven cases (63.6\%) and a duodenal tumor (adenoma) with no signs of chronic pancreatitis or malignancy in two cases (18\%). Interestingly cystic lesions or NET arising from a duodenal $\mathrm{PH}$ were not found in our symptomatic subgroup. Furthermore, no specific Heinrich's type was associated with symptoms or malignancy.

\section{Management of $\mathrm{PH}$}

For patients with symptomatic $\mathrm{PH}$, local resection of the lesion seems to be the most appropriate therapy [16]. Patients underwent partial duodenal resections in two cases due to a symptomatic PH with suspicion of a duodenal tumor after intraoperative exclusion of malignancy by frozen section. Although endoscopic therapy is currently being evaluated for removal of ectopic pancreatic tissue, surgery remains the standard therapy [31, 32]. If histologically proven $\mathrm{PH}$ is asymptomatic and malignancy is definitely excluded, it can be treated conservatively. Nevertheless, if $\mathrm{PH}$ is found incidentally during a surgical procedure, excision should be considered due to its potential for becoming symptomatic and malignant. If malignancy is suspected extended oncological surgical resection (e.g., PPPD) is justified. The prognosis of patients with adenocarcinoma arising from $\mathrm{PH}$ seems to be better compared to patients with tumors arising from the pancreas itself, probably due to earlier presentation [16, 33].

\section{Conclusion}

In summary, $\mathrm{PH}$ of the duodenum represents a rare diagnosis and most patients are asymptomatic. Duodenal $\mathrm{PH}$ is mostly diagnosed by histological evaluation of surgical specimens resected for different pathologies. Nevertheless, the present results indicate that nearly all diseases of the genuine pancreas can occur in heterotopic pancreatic tissue. Therefore, depending on the current disease, different symptoms can appear and lead to another diagnosis. Ectopic duodenal pancreatic tissue should be considered in the differential diagnosis when a duodenal lesion is detected. Surgical resection is indicated if the lesion is symptomatic or malignancy cannot be excluded.

\section{Abbreviations}

PDAC: Pancreatic ductal adenocarcinoma; NET: Neuroendocrine tumors; GIT: Gastrointestinal tract; PH: Pancreatic heterotopia; PPPD: Pyloruspreserving pancreatoduodenectomy; EUS-FNA: Endoscopic ultrasoundguided fine-needle aspiration

\section{Acknowledgements \\ We acknowledge the service of "PRS -Proof Reading Service" (Herfordshire, UK) for English language editing of the paper.}

\section{Funding}

There is no supporting fund.

\section{Availability of data and materials}

The datasets generated and analyzed during the current study may provide insight in clinical and personnel information about our patients. Therefore, these data cannot be made publically available. Access to the database can be obtained from the corresponding author on reasonable request.

\section{Authors' contributions}

$A B$ and MD wrote the manuscript, collected the data, interpreted the results and analyzed the data, STM and CZ interpreted the results and critically revised the manuscript, JP collected the data and wrote parts of the manuscript, SS analyzed the data statistically and corrected the manuscript, 
DEA performed histological examinations, JW and TW gave important manuscript corrections. All authors read and approved the final manuscript.

\section{Competing interests}

The authors declare that they have no competing interests.

\section{Consent for publication}

Not applicable.

\section{Ethics approval and consent to participate}

This study was designed as a retrospective analysis. In accordance with the guidelines for human subject research, approval was obtained from the ethics committee at the Carl Gustav Carus University Hospital (decision number EK 435102015). Informed consent was obtained as written format from patients. The personal information of all patients was protected.

\section{Publisher's Note}

Springer Nature remains neutral with regard to jurisdictional claims in published maps and institutional affiliations.

\section{Author details}

'Department of General, Thoracic and Vascular Surgery, University Hospital Carl Gustav Carus, TU Dresden, Fetscher Str. 74, 01037 Dresden, Germany. ${ }^{2}$ Institute for Pathology, University Hospital Carl Gustav Carus, TU Dresden, Fetscher Str. 74, 01307 Dresden, Germany.

\section{Received: 30 December 2016 Accepted: 2 May 2017}

Published online: 08 May 2017

\section{References}

1. Cano DA, Hebrok M, Zenker M. Pancreatic development and diseases. Gastroenterology. 2007:132:745-62

2. Jiang $L X, X u J$, Wang $X W$, et al. Gastric outlet obstruction caused by heterotopic pancreas: a case report and a quick review. World Gastroenterol. 2008;14:6757-9.

3. Barbosa JC, Dockerty M, Waugh JM. Pancreatic heterotopia. Review of the literature and report of 41 authenticated surgical cases of which 25 were clinically significant. Surg Gynecol Obstet. 1946;82:527-42.

4. Dolan RV, ReMine WH, Dockerty MB. The fate of heterotopic pancreatic tissue. A study of 212 cases. Arch Surg. 1974 Dec;109(6):762-5.

5. Shetty A, Paramesh AS, Dwivedi AJ, et al. Symptomatic ectopic pancreas. Clinical Review. 2002;58:203-7.

6. Pang LC. Pancreatic heterotopia: a reappraisal and clinicopathologic analysis of 32 cases. South Med J. 1988 Oct;81(10):1264-75.

7. Thoeni RF, Gedgaudas RK. Ectopic pancreas: usual and unusual features. Gastrointestinal Radiol. 1980;5:37-42.

8. Cattell RB, Warren KW. Surgery of the pancreas. Philadelphia: WB Saunders Co; 1953. p. 26-37

9. Hennings J, Garske U, Botling J, et al. Malignant insulinoma in ectopic pancreatic tissue. Dig Surg. 2005;22(5):377-9.

10. Jeong HY, Yang HW, Seo SW, et al. Adenocarcinoma arising from an ectopic pancreas in the stomach. Endoscopy. 2002 Dec;34(12):1014-7.

11. Tanaka K, Tsunoda T, Eto T, et al. Diagnosis and management of heterotopic pancreas. Int Surg. 1993 Jan-Mar;78(1):32-5.

12. Makhlouf HR, Almeida JL, Sobin LH. Carcinoma in jejunal pancreatic heterotopia. Arch Pathol Lab Med. 1999;123:707-11.

13. Guillou L, Nordback P, Gerber C, et al. Ductal adenocarcinoma arising in a heterotopic pancreas situated in a hiatal hernia. Arch Pathol Lab Med. 1994; 118:568-71.

14. Yuan Z, Chen J, Zheng Q, et al. Heterotopic pancreas in the gastrointestinal tract. World J Gastroenterol. 2009;15829:3701-3.

15. Chandan VS, Wang W. Pancreatic heterotopia in the gastric antrum. Arch Pathol Lab Med. 2004;128(1):111-2

16. Eisenberger CF, Gocht A, Knoefel WT, et al. Heterotopic pancreas-clinical presentation and pathology with review of the literature. HepatoGastroenterology. 2004 May-Jun;51(57):854-8. Review

17. Distler $M$, Rückert $F$, Aust $D$, et al. Pancreatic heterotopia of the duodenum: anatomic anomaly or clinical challenge ? J Gastrointest Surg. 2011;15:631-6.

18. Von Heinrich H. Ein Beitrag zur Histologie des sogenannten akzessorischen Pankreas. Virchows Arch A Pathol Anat Histopathol. 1909;198:392-440.
19. Elfving G, Hästbacka J. Pancreatic heterotopia and its clinical importance. Acta Chir Scand. 1965 Dec;130(6):593-602.

20. Armstrong CP, King PM, Dixon JM, et al. The clinical significance of heterotopic pancreas in the gastrointestinal tract. Br J Surg. 1981 Jun;68(6): 384-7.

21. Christodoulidis G, Zacharoulis D, Barbanis S, et al. Heterotopic pancreas in the stomach: a case report and literature review. World J Gastroenterol. 2007 Dec 7;13(45):6098-100.

22. Hsia CY, Wu CW, Lui WY. Heterotopic pancreas: a difficult diagnosis. J Clin Gastroenterol. 1999 Mar;28(2):144-7.

23. Trifan A, Tarcoveanu E, Danciu M, et al. Gastric heterotopic pancreas: an unusual case and review of the literature. J Gastrointestin Liver Dis. 2012;21: 209-12.

24. Kim JY, Lee JM, Kim KW, et al. Ectopic pancreas: CT findings with emphasis on differentiation from small gastrointestinal stromal tumor and leiomyoma. Radiology. 2009;252(1):92-100.

25. Martinez NS, Morlock CG, Dockerty MB, et al. Heterotopic pancreatic tissue involving the stomach. Ann Surg. 1958 Jan;147(1):1-12.

26. Chak A, Canto Ml, Rösch T, et al. Endosonographic differentiation of benign and malignant stromal cell tumors. Gastrointest Endosc. 1997 Jun;45(6):468-73.

27. Philipper M, Hollerbach S, Gabbert HE, et al. Prospective comparison of endoscopic ultrasound-guided fine-needle aspiration and surgical histology in upper gastrointestinal submucosal tumors. Endoscopy. 2010;42:300-5.

28. Burke GW, Binder SC, Barron AM, et al. Heterotopic pancreas: gastric outlet obstruction secondary to pancreatitis and pancreatic pseudocyst. Am J Gastroenterol. 1989 Jan;84(1):52-5.

29. Green PH, Barratt PJ, Percy JP, et al. Acute pancreatitis occurring in gastric aberrant pancreatic tissue. Am J Dig Dis. 1977 Aug;22(8):734-40.

30. Emerson L, Layfield $L$, Rohr LR, et al. Adenocarcinoma arising in association with gastric heterotopic pancreas: a case report and review of the literature. J Surg Oncol. 2004 Jul 15:87(1):53-7.

31. Vitello JM. Gastric intramural pseudocyst with associated gastric outlet obstruction: recognition and management. South Med J. 1996:89:534-7.

32. Holman GA, Parasher G. Extra-pancreatic pancreatitis: a rare cause of abdominal pain. Dig Dis Sci. 2014:59:1714-6.

33. Okamoto H, Kawaoi A, Ogawara T, et al. Invasive ductal carcinoma arising from an ectopic pancreas in the gastric wall: a long-term survival case. Case Rep Oncol. 2012;5:69-73.

\section{Submit your next manuscript to BioMed Central and we will help you at every step:}

- We accept pre-submission inquiries

- Our selector tool helps you to find the most relevant journal

- We provide round the clock customer support

- Convenient online submission

- Thorough peer review

- Inclusion in PubMed and all major indexing services

- Maximum visibility for your research

Submit your manuscript at www.biomedcentral.com/submit
Biomed Central 